\title{
Triple antiplatelet therapy for preventing vascular events: a systematic review and meta-analysis
}

\author{
Chamila Geeganage1, Robert Wilcox² and Philip MW Bath*1
}

\begin{abstract}
Background: Dual antiplatelet therapy is usually superior to mono therapy in preventing recurrent vascular events (VEs). This systematic review assesses the safety and efficacy of triple antiplatelet therapy in comparison with dual therapy in reducing recurrent vascular events.

Methods: Completed randomized controlled trials investigating the effect of triple versus dual antiplatelet therapy in patients with ischaemic heart disease (IHD), cerebrovascular disease or peripheral vascular disease were identified using electronic bibliographic searches. Data were extracted on composite VEs, myocardial infarction (MI), stroke, death and bleeding and analysed with Cochrane Review Manager software. Odds ratios (OR) and 95\% confidence intervals (Cl) were calculated using random effects models.

Results: Twenty-five completed randomized trials (17,383 patients with $H \mathrm{HD}$ ) were included which involving the use of intravenous (iv) GP Ilb/llla inhibitors (abciximab, eptifibatide, tirofiban), aspirin, clopidogrel and/or cilostazol. In comparison with aspirin-based therapy, triple therapy using an intravenous GP IIb/Illa inhibitor significantly reduced composite VEs and MI in patients with non-ST elevation acute coronary syndromes (NSTE-ACS) (VE: OR 0.69, 95\% CI 0.55-0.86; MI: OR 0.70, 95\% Cl 0.56-0.88) and ST elevation myocardial infarction (STEMI) (VE: OR 0.39, 95\% Cl 0.30-0.51; MI: OR 0.26, 95\% Cl 0.17-0.38). A significant reduction in death was also noted in STEMI patients treated with GP IIb/llla based triple therapy (OR 0.69, 95\% Cl 0.49-0.99). Increased minor bleeding was noted in STEMI and elective percutaneous coronary intervention (PCl) patients treated with GP IIb/Illa based triple therapy. Stroke events were too infrequent for us to be able to identify meaningful trends and no data were available for patients recruited into trials on the basis of stroke or peripheral vascular disease.

Conclusions: Triple antiplatelet therapy based on iv GPIIb/Illa inhibitors was more effective than aspirin-based dual therapy in reducing VEs in patients with acute coronary syndromes (STEMI and NSTEMI). Minor bleeding was increased among STEMI and elective PCI patients treated with a GP IIb/IIla based triple therapy. In patients undergoing elective $\mathrm{PCl}$, triple therapy had no beneficial effect and was associated with an $80 \%$ increase in transfusions and an eightfold increase in thrombocytopenia. Insufficient data exist for patients with prior ischaemic stroke and peripheral vascular disease and further research is needed in these groups of patients.
\end{abstract}

\section{Background}

Platelets contribute to the pathogenesis of different vascular syndromes including myocardial infarction (MI), ischaemic stroke and peripheral artery disease. Antiplatelet therapy offers partial prevention of these events[1-4]. The current therapeutic strategies for inhibiting platelets include: inhibition of cyclooxygenase (for example, aspirin [5]); inhibition of phosphodiesterases III and V and

\footnotetext{
* Correspondence: philip.bath@nottingham.ac.uk

1 Stroke Trials Unit, Institute of Neuroscience, Division of Stroke, University of Nottingham, City Hospital campus, Nottingham NG5 1PB, UK

Full list of author information is available at the end of the article
}

uptake by red cells of adenosine (for example, cilostazol, dipyridamole); blockade of the platelet ADP P2Y12 receptor (for example, ticlopidine, clopidogrel, prasugrel); blockade of glycoprotein IIb/IIIa receptors (which prevents fibrinogen binding); and increasing nitric oxide levels (for example, triflusal). While most antiplatelet agents are usually given orally, glycoprotein IIb/IIIa receptor antagonists can be given intravenously (for example, abciximab, eptifibatide, tirofiban) or orally (for example, lotrafiban, orbofiban, sibrafiban, xemilofiban). However, oral IIb/IIIa receptor antagonists have been abandoned due to an increase in death in several trials[6]. 
Individual antiplatelet agents reduce recurrent events by $15 \%-20 \%$, as seen with aspirin and dipyridamole $[7,8]$ and from indirect comparisons for clopidogrel, triflusal and cilostazol[9-11]. These drugs have different mechanisms of action so their combination is likely to be additive and more effective in reducing vascular events than monotherapy, a hypothesis confirmed for aspirin and clopidogrel [12-15] and aspirin and dipyridamole $[8,16]$. As a result, guidelines now recommend dual combinations for patients with non-ST elevation with acute coronary syndromes (NSTE-ACS), ST elevation with myocardial infarction (STEMI), percutaneous coronary infarction (PCI) and ischaemic stroke/transient ischaemic attack (TIA) [17-20]. However, the combination of aspirin and clopidogrel is not recommended for longterm prophylaxis (> 12 months) against stroke because of excess bleeding, as seen in MATCH and CHARISMA[21,22]. Further, in the setting of high risk NSTEACS (patients having elevated troponins, ST depression, or diabetes) addition of eptifibatide or tirofiban to oral antiplatelet agents is recommended for initial early treatment (class II, a level A)[19,20]. Addition of abciximab to aspirin and clopidogrel is also recommended in both NSTE-ACS and STEMI patients undergoing PCI (for NSTE-ACS class 11 level B)[19,20]. However, in patients with recent stroke, the PRoFESS trial found that the combination of aspirin plus extended release dipyridamole versus clopidogrel had a comparable effect on secondary stroke prevention[23]. However, the benefit of combined antiplatelet therapy during high risk acute ischaemic stroke/TIAs is still unknown.

If two agents are superior to one, then three might be even better providing that bleeding does not become a limiting factor. Several randomized trials have compared triple antiplatelet therapy with dual therapy and we have assessed these in a systematic review involving patients with ischaemic vascular diseases.

\section{Methods}

\section{Ethics}

No ethical approval was required for this study.

\section{Search strategy}

Completed randomized controlled trials that investigated the effect of triple antiplatelet versus dual antiplatelet therapy in the prevention of vascular events in patients with ischaemic vascular diseases [stroke/TIA, ischaemic heart disease (IHD), peripheral vascular disease (PVD)] were sought with searches (October 2009) of electronic databases including Cochrane Library (issue 4 2009), EMBASE, MEDLINE and Science Citation Index (ISI Web of Science). Separate search strategies were developed for each database using the following keywords: 'triple antiplatelet therapy', 'aggressive antiplatelet therapy', 'combined antiplatelet therapy', 'antiplatelet therapy', 'aspirin', 'dipyridamole', 'clopidogrel', 'ticlopidine', 'prasugrel' 'cilostazol', 'triflusal', 'abciximab', 'tirofiban', 'eptifibatide', 'ST elevation myocardial infarction', 'non-ST elevation acute coronary syndrome', 'stroke', 'transient ischaemic attack', 'acute limb ischaemia', 'peripheral arterial/vascular disease', 'vascular events', 'randomized controlled trials' and 'controlled clinical trials'. Reference lists of earlier reviews $[24,25]$ and identified trial publications were also checked for additional trials. Where duplicate publications were identified, data from the primary report were used. Publications could be in any language.

\section{Selection}

Completed randomized, placebo or open-label, controlled trials were included where adult patients who were at high risk of ischaemic VEs were enrolled: NSTEACS; STEMI; PVD; acute ischaemic stroke; TIA; and previous $\mathrm{MI} /$ or coronary artery disease (secondary prevention), including elective PCI; previous stroke and/or TIA; and peripheral arterial disease. Patients had to have been treated with triple antiplatelet therapy versus dual antiplatelet therapy. Trials where only a sub-set of patients were offered triple therapy were not included.

\section{Validity assessment}

Trials were identified based on the inclusion/exclusion criteria discussed above. Methodological quality of the trials was assessed in relation to randomization and concealment of allocation. A quality scale was used to assess the trials: (A) true randomization and allocation concealed; and (B) process of randomisation not given and concealment of allocation unclear. This approach is recommended by the Cochrane collaboration[26].

\section{Data abstraction}

Two reviewers identified and assessed published trials. One author resolved disagreements on studies by discussion $(\mathrm{PB})$.

\section{Study characteristics}

The following information were extracted by treatment group: (i) treatment, including type and route of antiplatelet administration, treatment window, length of treatment, and follow up period; (ii) number of patients; and (iii) outcome, this encompassing: composite vascular events (non fatal stroke, non-fatal myocardial infarction or death), myocardial infarction, ischaemic stroke, death, major bleeding, intracranial bleeding, minor bleeding, blood transfusions and thrombocytopenia. Outcome events were based on the definitions used in the individual trial publications. The primary outcome comprised composite vascular events; other events were regarded as secondary outcomes. 


\section{Quantitative data synthesis}

Data were entered into and analysed using the Cochrane Collaboration Review Manager software (version 4.2). Data were analysed separately by indication (NSTE-ACS, STEMI, PCI, ischaemic stroke, TIA, PVD and indicator drug in addition to the overall assessment of each vascular outcome. Odds ratios (OR) and 95\% confidence intervals $(\mathrm{CI})$ were calculated; random-effects models were used since heterogeneity was expected among the trials taking account that different antiplatelet agents and patient populations were being studied. Heterogeneity was calculated using the Chi-squared and $\mathrm{I}^{2}$ statistics. An $\mathrm{OR}<1$ suggests a beneficial effect whilst an OR $>1$ suggest a detrimental drug effect. Absolute event rates for composite VE (primary outcome) and bleeding were calculated. The event rates for patients receiving triple therapy was calculated from the relative risk and control event rate for each outcome because the unequal randomization in some trials makes exact rates in the treatment group unreliable ('Simpson paradox'). Egger's test and Beggs funnel-plot were performed to assess any publication bias in included trials[27].

\section{Results}

\section{Trial flow/flow of included studies}

Twenty-five completed randomized trials fulfilled the inclusion criteria (Table 1) and included 17,383 patients (Figure 1). Seven trials (771 patients) were excluded (Figure 1), mostly because they did not provide relevant outcome data or did not have a control group; an eighth trial is ongoing.

\section{Study characteristics}

The included trials studied three patient populations: NSTE-ACS (four trials), STEMI (8) and elective PCI (13) (Table 1). No studies in patients with previous stroke or PVD were identified. Each of the 25 trials was randomized and 17 had concealed allocation; allocation concealment was unclear in eight studies[28-35]. All trials compared triple antiplatelet therapy with dual therapy (Table 1). Most trials used an intravenous GP IIb/IIIa receptor antagonist as the additional antiplatelet agent (no studies used an oral GP IIb/IIIa receptor antagonist, presumably because of hazard with these agents [6]); the remaining trials used clopidogrel or cilostazol as the extra agents. No triple therapy trials involved dipyridamole, triflusal or prasugrel. Twenty trials gave concomitant heparin to both treatment groups. Hence, the comparison of triple versus conventional antiplatelet therapy was not confounded (Table 1). No evidence of publication bias using Egger's test ( $P$ for bias 0.97 ) was present and there was no asymmetry on visual inspection of the Begg's funnel plot (not shown).

\section{Quantitative data synthesis GP IIb/IIla inhibitors}

A $30 \%$ reduction in composite vascular events (non fatal stroke, non-fatal myocardial infarction or death) and MI alone were seen when GP IIb/IIIa inhibitors were added to dual antiplatelet therapy in patients with NSTE-ACS (Table 2, Figures 2 and 3); a similar magnitude reduction in death was also present although this was non-significant due to the small number of events. Similarly, vascular events and MI were reduced by $60 \%-70 \%$ in patients with STEMI with the addition of GP IIb/IIIa inhibitors; death was also reduced by $30 \%$ (Table 2, Figure 4). GPIIb/ IIIa inhibitors were significantly more effective in preventing vascular events and MI in patients with STEMI than NSTEMI (chi-square $=10.7,1 \mathrm{df}, P<0.01$; chisquare $=18.8,1 \mathrm{df}, P<0.001$, respectively). Trends to reduced vascular events; $\mathrm{MI}$ and death were present for GPIIb/IIIa based triple therapy in patients having elective PCI. Only six ischaemic strokes were recorded as an outcome and these came from just four studies; when assessed there was no difference in ischaemic stroke between triple and dual antiplatelet therapy (OR 1.74, 95\% CI 0.35-8.65, $P=0.5, \mathrm{I}^{2}=0 \%$ ).

\section{Other agents}

Neither clopidogrel nor cilostazol, when added to dual antiplatelet therapy (based either aspirin + clopidogrel or aspirin + GP IIb/IIIa inhibitor), had significant effects on vascular events in patients with STEMI or having elective PCI (Table 2). However, the number of trials and patients in the comparisons was relatively small.

\section{Adverse events}

A significant increase in minor bleeding (and trend to increase in major bleeding) was seen with the use of GP IIb/IIIa based triple therapy in patients with STEMI or having PCI (Table 3). As a result, transfusion needs were increased by $80 \%$ with GP IIb/IIIa based triple therapy in elective PCI patients. Thombocytopenia was increased eightfold with GP IIb/IIIb based triple therapy in elective PCI patients (Table 3 ).

\section{Absolute event rates}

Absolute event rates for composite vascular event, major bleeding and minor bleeding are shown in Figure 5. The number of patients benefiting from triple antiplatelet therapy (reduced composite vascular event) was much larger than the number suffering from major bleeding (Figure 5).

\section{Discussion}

The premise of this systematic review was that if two antiplatelet agents are usually superior to one, then three might be better still. Multiple trials were identified which included different groups of patients (NSTE-ACS, 


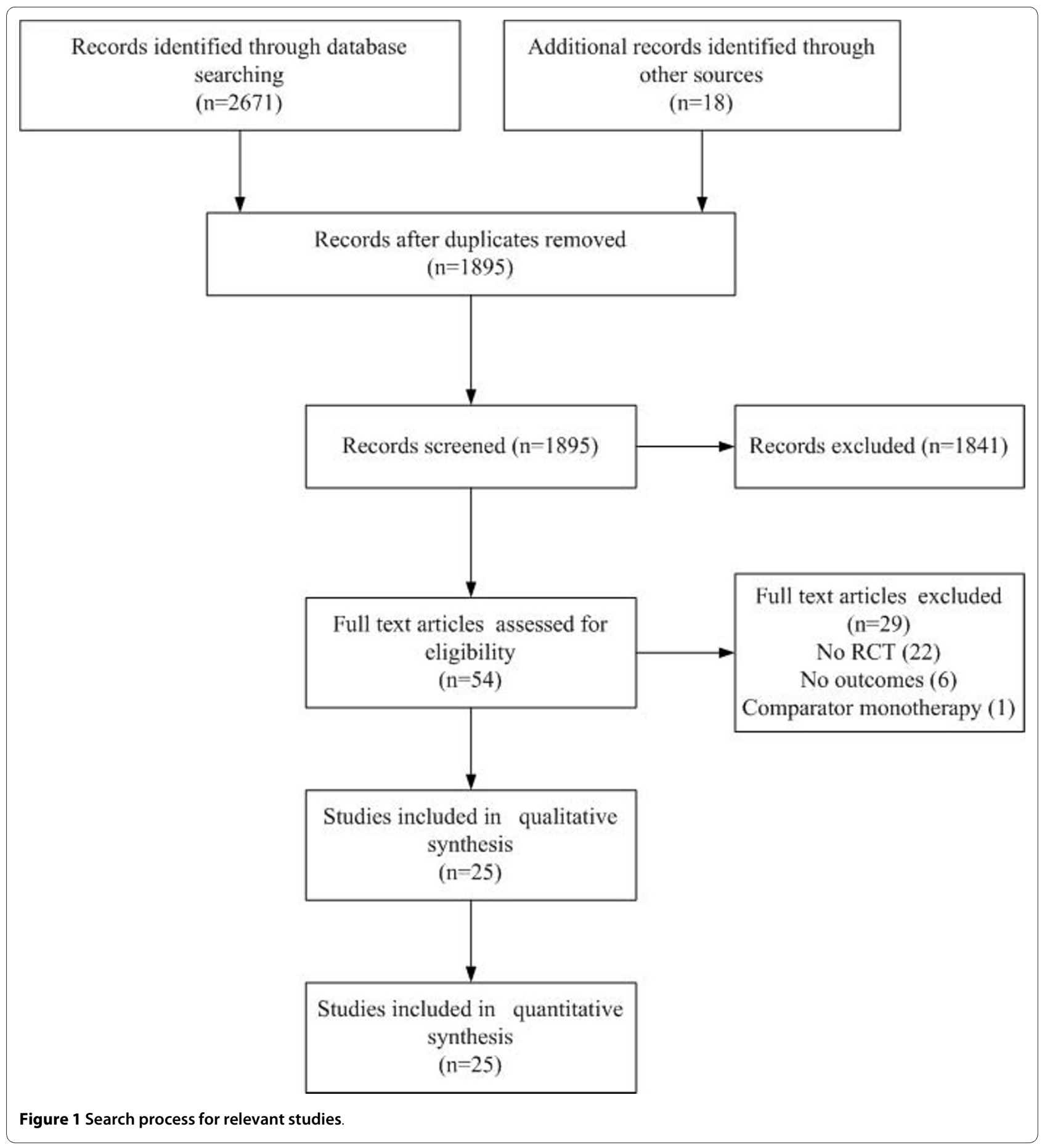

STEMI, elective PCI) and add-on drugs (GPIIb/IIIa inhibitors, clopidogrel, cilostazol). The results confirmed that triple antiplatelet therapy involving the addition of an intravenous GPIIb/IIIa receptor antagonist is more effective than dual therapy in reducing vascular events and MI in patients with NSTE-ACS or STEMI. Death was also reduced in those with STEMI. Interestingly, the relative reduction in events appears to be greater in patients with STEMI than NSTE-ACS. A non-significant trend towards a reduction in vascular outcomes was also found in elective PCI patients when treated with a GPIIb/IIIa receptor antagonist, a finding also reported in one other systematic review [24]. In contrast, triple antiplatelet therapy based on oral cilostazol had no effect on vascular outcomes in STEMI and elective PCI patients. Similar results were noted for clopidogrel based triple therapy although this assessment was based on few patients and may reflect a type II error. 
Table 1: Included randomized controlled trials.

\begin{tabular}{|c|c|c|c|c|c|c|c|c|c|c|c|}
\hline \multirow[b]{2}{*}{ Study } & \multirow[b]{2}{*}{$\mathbf{N}$} & \multirow[b]{2}{*}{ Age } & \multirow[b]{2}{*}{$\begin{array}{c}\text { Male } \\
(\%)\end{array}$} & \multicolumn{3}{|c|}{ Control group } & \multirow[b]{2}{*}{$\begin{array}{l}\text { Triple } \\
\text { group }\end{array}$} & \multirow[b]{2}{*}{ Heparin } & \multirow[b]{2}{*}{$\begin{array}{l}\text { Length of } \\
\text { treatment }\end{array}$} & \multirow[b]{2}{*}{$\begin{array}{l}\text { Length of } \\
\text { follow-up } \\
\text { (months) }\end{array}$} & \multirow[b]{2}{*}{ Quality* } \\
\hline & & & & Asp & TP & GP & & & & & \\
\hline \multicolumn{12}{|l|}{ NSTE-ACS } \\
\hline ADVANCE[41] & 202 & 69 & 68 & $\sqrt{ }$ & $\sqrt{ }$ & & Tirofiban & $\sqrt{ }$ & $48 \mathrm{~h}$ & 6 & A \\
\hline ELISA-2[42] & 328 & 64 & 71 & $\sqrt{ }$ & $\sqrt{ }$ & & Tirofiban & - & $12 \mathrm{~h}$ & 1 & A \\
\hline ISAR-REACT-2[43] & 2,022 & 66 & 75 & $\sqrt{ }$ & $\sqrt{ }$ & & Abciximab & $\sqrt{ }$ & $12 \mathrm{~h}$ & 1 & $A$ \\
\hline PROTECT-TIMI-30[44] & 857 & 60 & 67 & $\sqrt{ }$ & $\sqrt{ }$ & & Eptifibatide & $\sqrt{ }$ & $24 \mathrm{~h}$ & $48 \mathrm{~h}$ & A \\
\hline \multicolumn{12}{|l|}{ STEMI } \\
\hline ADMIRAL[45] & 300 & 61 & 82 & $\sqrt{ }$ & $\sqrt{ }$ & & Abciximab & $\sqrt{ }$ & $12 \mathrm{~h}$ & 6 & A \\
\hline ACE[46] & 400 & 64 & 77 & $\sqrt{ }$ & $\sqrt{ }$ & & Abciximab & $\sqrt{ }$ & $12 \mathrm{~h}$ & 6 & $A$ \\
\hline CADILLAC [47] & 2082 & 60 & 73 & $\sqrt{ }$ & $\sqrt{ }$ & & Abciximab & $\sqrt{ }$ & $12 \mathrm{~h}$ & 6 & B \\
\hline Ernst/1[48] & 60 & 61 & 74 & $\sqrt{ }$ & $\sqrt{ }$ & & Abciximab & $\sqrt{ }$ & $12 \mathrm{~h}$ & 1 & B \\
\hline Ernst/2[48] & 60 & 60 & 82 & $\sqrt{ }$ & $\sqrt{ }$ & & Tirofiban & $\sqrt{ }$ & $12 \mathrm{~h}$ & 1 & B \\
\hline Ernst/3[48] & 59 & 61 & 76 & $\sqrt{ }$ & $\sqrt{ }$ & & Tirofiban high dose & $\sqrt{ }$ & $12 \mathrm{~h}$ & 1 & $\mathrm{~B}$ \\
\hline ISAR 2[30] & 401 & 61 & 76 & $\sqrt{ }$ & $\sqrt{ }$ & & Abciximab & $\sqrt{ }$ & $12 \mathrm{~h}$ & 1 & B \\
\hline Neumann[31] & 200 & 60 & 77 & $\sqrt{ }$ & $\sqrt{ }$ & & Abciximab & $\sqrt{ }$ & $12 \mathrm{~h}$ & 1 & $\mathrm{~B}$ \\
\hline Petronio[49] & 31 & 57 & 87 & $\sqrt{ }$ & $\sqrt{ }$ & & Abciximab & $\sqrt{ }$ & $12 \mathrm{~h}$ & 1 & B \\
\hline $\operatorname{Kim}[50]$ & 60 & 63 & 70 & $\sqrt{ }$ & $\sqrt{ }$ & & Cilostazol & $\sqrt{ }$ & 1 month & 1 & $\mathrm{~B}$ \\
\hline \multicolumn{12}{|l|}{ Elective PCI } \\
\hline Claeys[51] & 200 & 67 & 70 & $\sqrt{ }$ & $\sqrt{ }$ & & Abciximab & $\sqrt{ }$ & $12 \mathrm{~h}$ & 6 & B \\
\hline EPISTENT[52] & 1,603 & 59 & 75 & $\sqrt{ }$ & $\sqrt{ }$ & & Abciximab & $\sqrt{ }$ & $13 \mathrm{~h}$ & 1 & $A$ \\
\hline ESPRIT[35] & 2,064 & 62 & 73 & $\sqrt{ }$ & $\sqrt{ }$ & & Eptifibatide & $\sqrt{ }$ & $24 \mathrm{~h}$ & 1 & B \\
\hline ISAR-REACT[53] & 2,159 & 66 & 77 & $\sqrt{ }$ & $\sqrt{ }$ & & Abciximab & $\sqrt{ }$ & $12 \mathrm{~h}$ & 1 & A \\
\hline ISAR-SMART-2[54] & 502 & 66 & 73 & $\sqrt{ }$ & $\sqrt{ }$ & & Abciximab & $\sqrt{ }$ & $12 \mathrm{~h}$ & 12 & A \\
\hline ISAR-SWEET[55] & 701 & 68 & 75 & $\sqrt{ }$ & $\sqrt{ }$ & & Abciximab & $\sqrt{ }$ & $12 \mathrm{~h}$ & 12 & A \\
\hline TOPSTAR[56] & 96 & 65 & 75 & $\sqrt{ }$ & $\sqrt{ }$ & & tirofiban & $\sqrt{ }$ & $42 \mathrm{~h}$ & 9 & A \\
\hline MR PCl/1[57] & 60 & 61 & 85 & $\sqrt{ }$ & - & $\sqrt{ }$ & Clopidogrel & $\sqrt{ }$ & 30 days & 1 & A \\
\hline MR PCl/2[57] & 60 & 56 & 85 & $\sqrt{ }$ & - & $\sqrt{ }$ & Clopidogrel & $\sqrt{ }$ & 30 days & 1 & A \\
\hline DECLARE-Long[58] & 500 & 61 & 64 & $\sqrt{ }$ & $\sqrt{ }$ & & Cilostazol & - & 6 months & 6 & A \\
\hline DECLARE-DIABETES[59] & 400 & 61 & 58 & $\sqrt{ }$ & $\sqrt{ }$ & & Cilostazol & - & 6 months & 6 & A \\
\hline $\operatorname{Min}[60]$ & 59 & 62 & 66 & $\sqrt{ }$ & $\sqrt{ }$ & & Cilostazol & $\sqrt{ }$ & 1 month & 6 & A \\
\hline CREST[61] & 705 & 60 & 74 & $\sqrt{ }$ & $\sqrt{ }$ & & Cilostazol & - & 6 months & 6 & A \\
\hline $\operatorname{Han}[62]$ & 1212 & 60 & 73 & $\sqrt{ }$ & $\sqrt{ }$ & & Cilostazol & - & 6 months & 12 & A \\
\hline
\end{tabular}

*Quality scale: A, true randomization and allocation concealed; B, process of randomization not given and concealment of allocation unclear. Asp, aspirin; GP, glycoprotein Ilb/Illa receptor antagonists (abciximab, tirofiban, eptifibatide); MI, myocardial infarction; NSTEACS, non-ST elevation acute coronary syndrome; PCl, percutaneous coronary interventions; TP, thienopyridine (clopidogrel, ticlopidine).

Previous meta-analysis involving the addition of iv GPIIb/IIIa inhibitors in the setting of STEMI has revealed conflicting results. One meta-analysis involving six STEMI trials showed no significant reduction in death or recurrent MI[36]. Another showed abciximab as an adjunctive therapy to STEMI patients undergoing stent implantation (but not balloon angioplasty) reduced mortality and recurrent MI[37]. A third meta-analysis involving patients with STEMI undergoing primary angioplasty found that, combined reduced dose thrombolytic therapy and GPIIb/IIIa inhibitors was not superior to Gp IIb-IIIa inhibitors alone[38]. A fourth meta-analysis involving five 


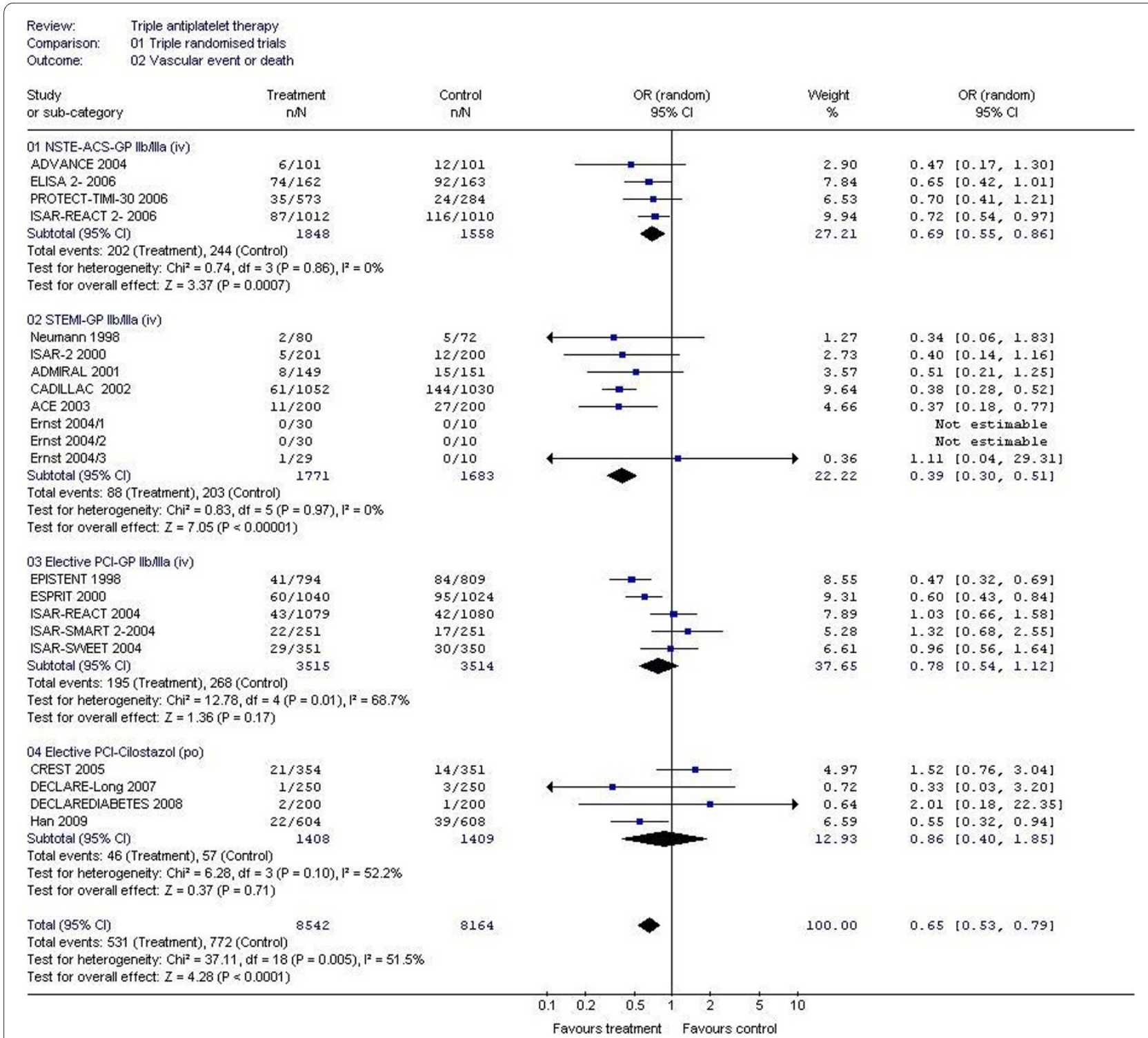

Figure 2 The effect of triple antiplatelet therapy on vascular event or death

STEMI trials showed that the use of abciximab in primary stenting may reduce death or MI in patients without preprocedural thienopyridine therapy (but not in those who received thienopyridines)[39]. The present meta-analysis revealed that the addition of iv GPIIb/IIIa inhibitors in the treatment of STEMI patients reduces death, MI and composite vascular outcome. However, the analysis did not include the effects of GPIIb/IIIa inhibitors among different revascularization therapies of STEMI patients.

Unsurprisingly, bleeding events tended to be higher in patients receiving triple antiplatelet therapy although only the analyses involving a GPIIb/IIIa receptor antagonist were associated with significant increases in minor bleeding, this being present in patients with STEMI and elective PCI. Supporting this observation was a need for more blood transfusions in elective PCI. Additionally, treatment with a GPIIb/IIIa receptor antagonist was also associated with an increased risk of thrombocytopenia, again in patients having PCI. However, the balance between treatment efficacy and hazard remains favourable for triple antiplatelet therapy as shown by changes in the absolute event rates for composite vascular event and major bleeding.

Importantly, the duration of randomised treatment was short (12-48 h) in most trials apart from four cilostazol trials where patients received treatment for 6 months (Table 1). Further, trial follow-up was also short varying between 1-12 months. Hence, the superiority of intravenous GPIIb/IIIa receptor antagonist based triple anti- 


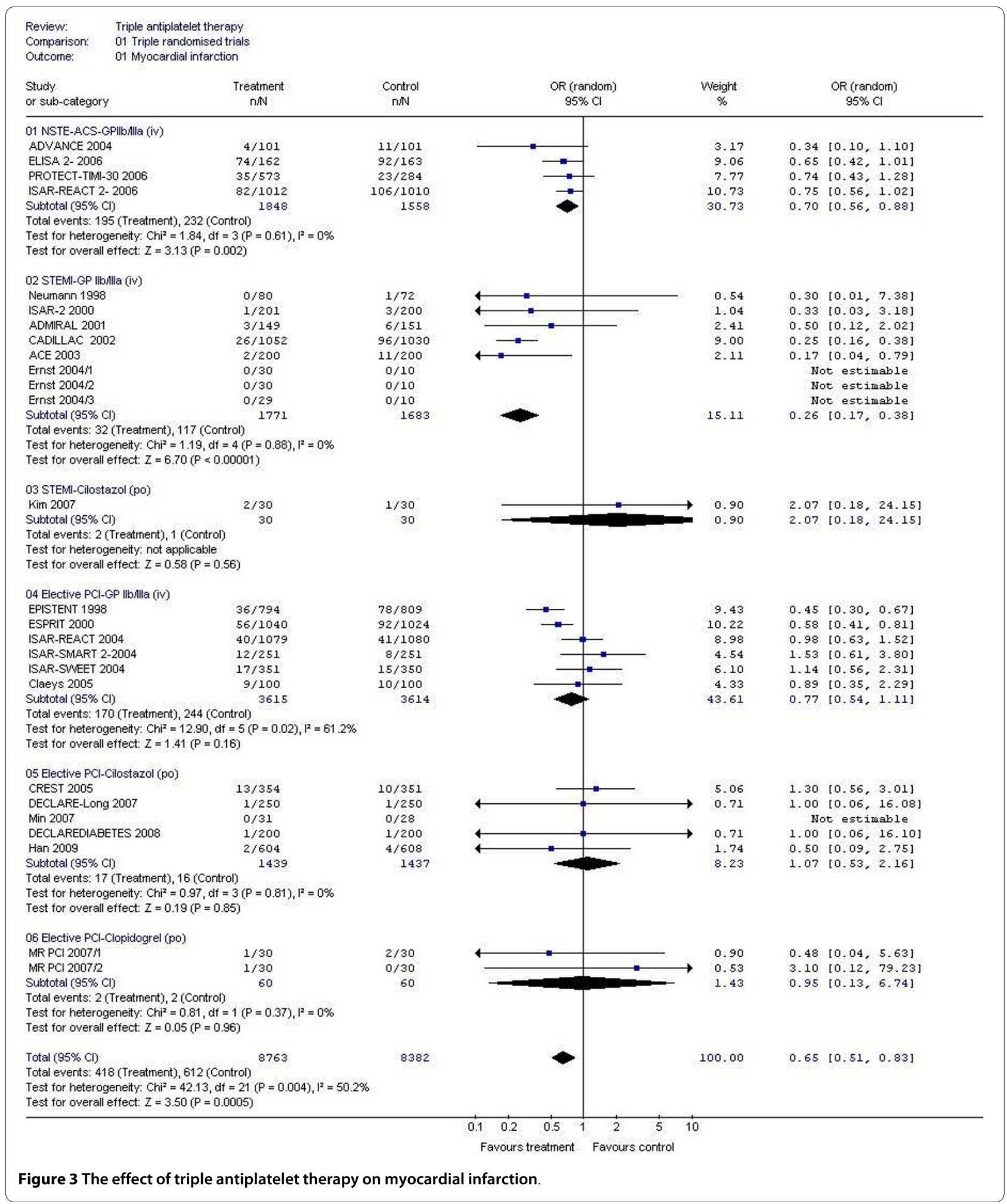

platelet therapy should only be considered for short-term treatment. Also important is that most of the trials gave concomitant heparin to all patients (amounting to quadruple antithrombotic therapy in patients receiving three antiplatelets), which may have contributed to increased bleeding rates. Heparin might also explain the increased rate of thrombocytopenia although the treatment duration was short while thrombocytopenia rates, but not heparin administration, differed between the treatment groups. In the present analysis methodological quality of 


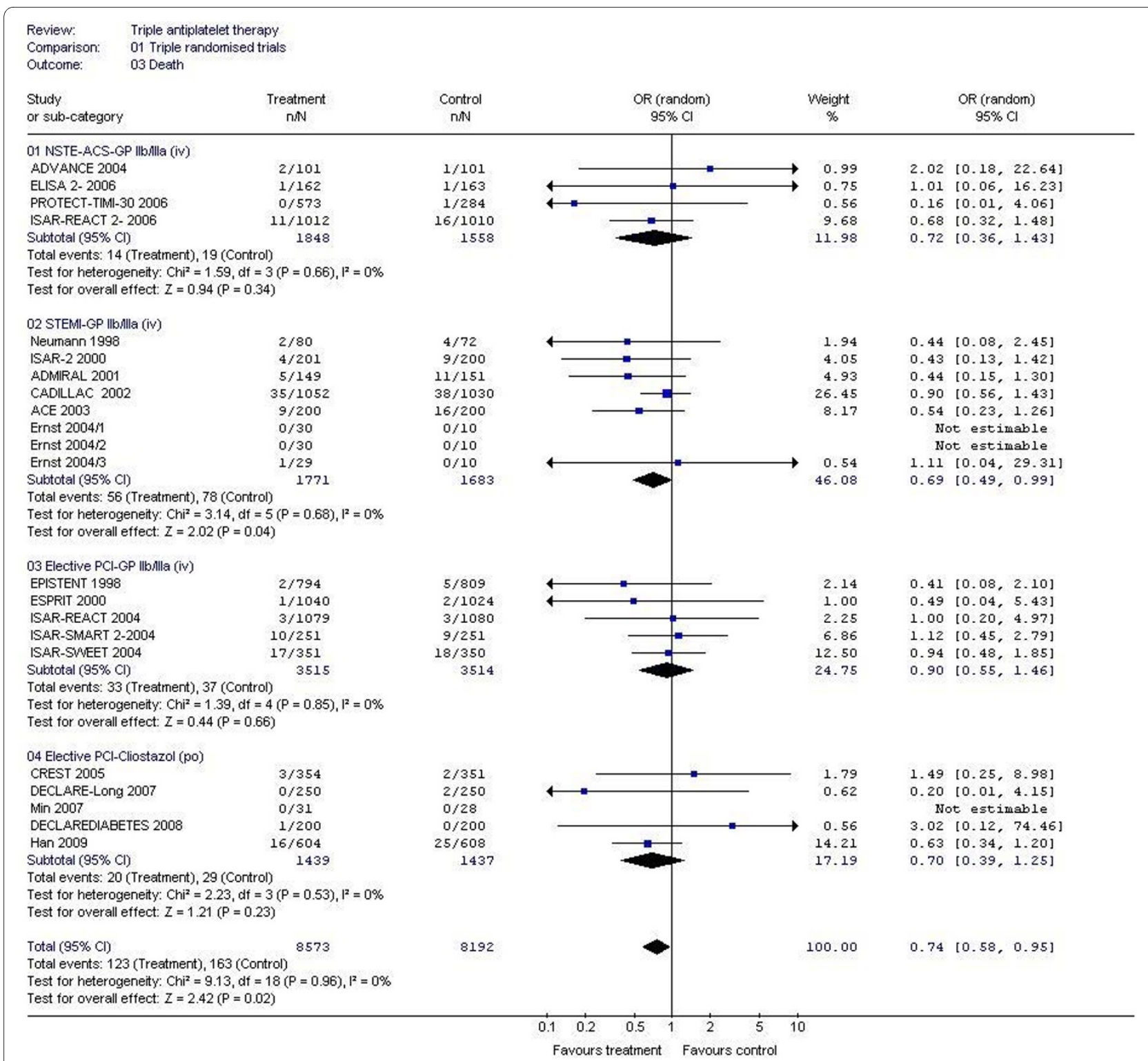

Figure 4 The effect of triple antiplatelet therapy on death

the trials were assessed in relation to method of randomization and concealment of allocation. Other important factors such as blinding and loss to follow-up that could also influence methodological quality were not assessed in the present analysis.

Whilst the results are clear for patients with STEMI, NSTE-ACS and PCI, there were only very limited data on stroke outcome events and it is not clear whether triple antiplatelet therapy is beneficial among stroke patients. The search process identified one trial of triple antiplatelet therapy performed in 17 patients with chronic ischaemic stroke or TIA (not included in this analysis as it compared triple antiplatelet therapy with aspirin based monotherapy)[40]. Hence, the role of triple therapy in patients with ischaemic cerebrovascular disease cannot be commented on. No trials comparing triple versus dual antiplatelet therapy in patients with PVD was found.

\section{Conclusions}

Triple antiplatelet therapy based on iv GPIIb/IIIa inhibitors was more effective than aspirin-based dual therapy in reducing vascular events, MI and death in patients with acute coronary syndromes (STEMI and NSTEMI). A significant increase in minor bleeding complications was observed among STEMI and elective PCI patients treated with a GP IIb/IIIa based triple therapy. In patients undergoing elective PCI, triple therapy had no beneficial effect and was associated with an $80 \%$ increase in transfu- 
Table 2: Summary of efficacy for triple antiplatelet therapy in randomised controlled trials (significant effects are in bold).

\begin{tabular}{|c|c|c|c|c|c|c|c|c|c|c|}
\hline \multirow[t]{2}{*}{ Patients } & \multirow[t]{2}{*}{ Intervention } & \multicolumn{3}{|c|}{ Myocardial infarction } & \multicolumn{3}{|c|}{ Composite vascular event } & \multicolumn{3}{|c|}{ Death } \\
\hline & & $\begin{array}{l}\text { Triple } \\
\text { events/total }\end{array}$ & $\begin{array}{l}\text { Control } \\
\text { events/total }\end{array}$ & $\begin{array}{l}\text { OR }^{*} \\
(95 \% \mathrm{Cl})\end{array}$ & $\begin{array}{l}\text { Triple } \\
\text { events/total }\end{array}$ & $\begin{array}{l}\text { Control } \\
\text { events/total }\end{array}$ & $\begin{array}{c}\mathrm{OR}^{*} \\
(95 \% \mathrm{Cl})\end{array}$ & $\begin{array}{l}\text { Triple } \\
\text { events/total }\end{array}$ & $\begin{array}{c}\text { Control } \\
\text { events/total }\end{array}$ & OR* $(95 \% \mathrm{Cl})$ \\
\hline NSTE-ACS & GP IIb/IIla & $195 / 1848$ & $232 / 1558$ & $0.70(0.56-0.88)$ & $202 / 1848$ & $244 / 1558$ & $0.69(0.55-0.86)$ & $14 / 1848$ & $19 / 1558$ & $0.72(0.36-1.43)$ \\
\hline \multirow[t]{2}{*}{ STEMI } & GP IIb/IIla & $32 / 1771$ & $117 / 1683$ & $0.26(0.17-0.38)$ & $88 / 1771$ & $203 / 1683$ & $0.39(0.30-0.51)$ & $56 / 1771$ & $78 / 1683$ & $0.69(0.49-0.99)$ \\
\hline & Cilostazol & $2 / 30$ & $1 / 30$ & $2.07(0.18-24.15)$ & & & & & & \\
\hline \multirow[t]{3}{*}{ Elective PCl } & GP IIb/IIla & $170 / 3615$ & $244 / 3614$ & $0.77(0.54-1.11)$ & $195 / 3515$ & $268 / 3514$ & $0.78(0.54-1.12)$ & $33 / 3515$ & $37 / 3514$ & $0.90(0.55-1.46)$ \\
\hline & Cilostazol & $17 / 1439$ & $16 / 1437$ & $1.07(0.53-2.16)$ & $46 / 1408$ & $57 / 1409$ & $0.86(0.40-1.85)$ & $20 / 1439$ & $29 / 1437$ & $0.70(0.39-1.25)$ \\
\hline & Clopidogrel & $2 / 60$ & $2 / 60$ & $0.95(0.13-6.74)$ & & & & & & \\
\hline
\end{tabular}

*Odds ratios (OR) were calculated from random effect models.

$\mathrm{Cl}$, confidence interval; NSTE-ACS, non-ST elevation acute coronary syndromes; STEMI, ST elevation myocardial infarction; PCl, percutaneous coronary intervention. 
Table 3: Summary of adverse events during triple antiplatelet therapy(significant effects are in bold).

\begin{tabular}{|c|c|c|c|c|c|c|c|c|c|c|c|c|c|}
\hline \multirow[t]{2}{*}{ Patients } & \multirow[t]{2}{*}{ Intervention } & \multicolumn{3}{|c|}{ Major bleeding } & \multicolumn{3}{|c|}{ Minor bleeding } & \multicolumn{3}{|c|}{ Blood transfusions } & \multicolumn{3}{|c|}{ Thrombocytopenia } \\
\hline & & $\begin{array}{l}\text { Triple } \\
\text { events/total }\end{array}$ & $\begin{array}{l}\text { Control } \\
\text { events/total }\end{array}$ & OR $*(95 \% \mathrm{Cl})$ & $\begin{array}{l}\text { Triple } \\
\text { events/total }\end{array}$ & $\begin{array}{l}\text { Control } \\
\text { events/total }\end{array}$ & $\mathrm{OR}^{*}(95 \% \mathrm{Cl})$ & $\begin{array}{l}\text { Triple } \\
\text { events/total }\end{array}$ & $\begin{array}{l}\text { Control } \\
\text { events } \\
\text { /total }\end{array}$ & $\mathrm{OR}^{*}(95 \% \mathrm{Cl})$ & $\begin{array}{c}\text { Triple } \\
\text { events/total }\end{array}$ & $\begin{array}{c}\text { Control } \\
\text { events/total }\end{array}$ & $\mathrm{OR}^{*}(95 \% \mathrm{Cl})$ \\
\hline NSTE-ACS & GP IIb/llla & $34 / 1275$ & $30 / 1274$ & $1.15(0.69-1.91)$ & $46 / 1113$ & $34 / 1111$ & $1.37(0.81-2.33)$ & $45 / 1174$ & $36 / 1173$ & $1.27(0.81-2.00)$ & $8 / 1012$ & $0 / 1010$ & $17.1(0.99-296.69)$ \\
\hline \multirow[t]{2}{*}{ STEMI } & GP IIb/IIla & $11 / 255$ & $2 / 195$ & $1.86(0.43-8.17)$ & $23 / 255$ & $7 / 195$ & $2.73(1.15-6.46)$ & $10 / 281$ & $15 / 272$ & $0.63(0.28-1.44)$ & $11 / 238$ & $4 / 181$ & $1.51(0.48-4.71)$ \\
\hline & Cilostazol & $0 / 30$ & $0 / 30$ & & & & & & & & & & \\
\hline \multirow[t]{3}{*}{ Elective PCI } & GP IIb/IIla & $42 / 3314$ & $34 / 3309$ & $1.29(0.70-2.36)$ & $99 / 3314$ & $62 / 3309$ & $1.60(1.16-2.21)$ & $71 / 3264$ & $40 / 3263$ & $1.79(1.14-2.79)$ & $17 / 2269$ & $0 / 2250$ & $8.04(1.82-35.59)$ \\
\hline & Cilostazol & $0 / 1054$ & $1 / 1058$ & $0.33(0.01-8.24)$ & $6 / 1054$ & $7 / 1058$ & $0.85(0.28-2.56)$ & & & & $1 / 450$ & $2 / 450$ & $0.62(0.08-5.09)$ \\
\hline & Clopidogrel & $1 / 60$ & $0 / 60$ & $3.10(0.12-79.29)$ & $1 / 60$ & $0 / 60$ & $3.10(0.12-79.23)$ & & & & & & \\
\hline
\end{tabular}

*Odds ratios were calculated from random effect models.

NSTE-ACS, non-ST elevation acute coronary syndromes; STEMI, ST elevation myocardial infarction; PCl, percutaneous coronary intervention. 


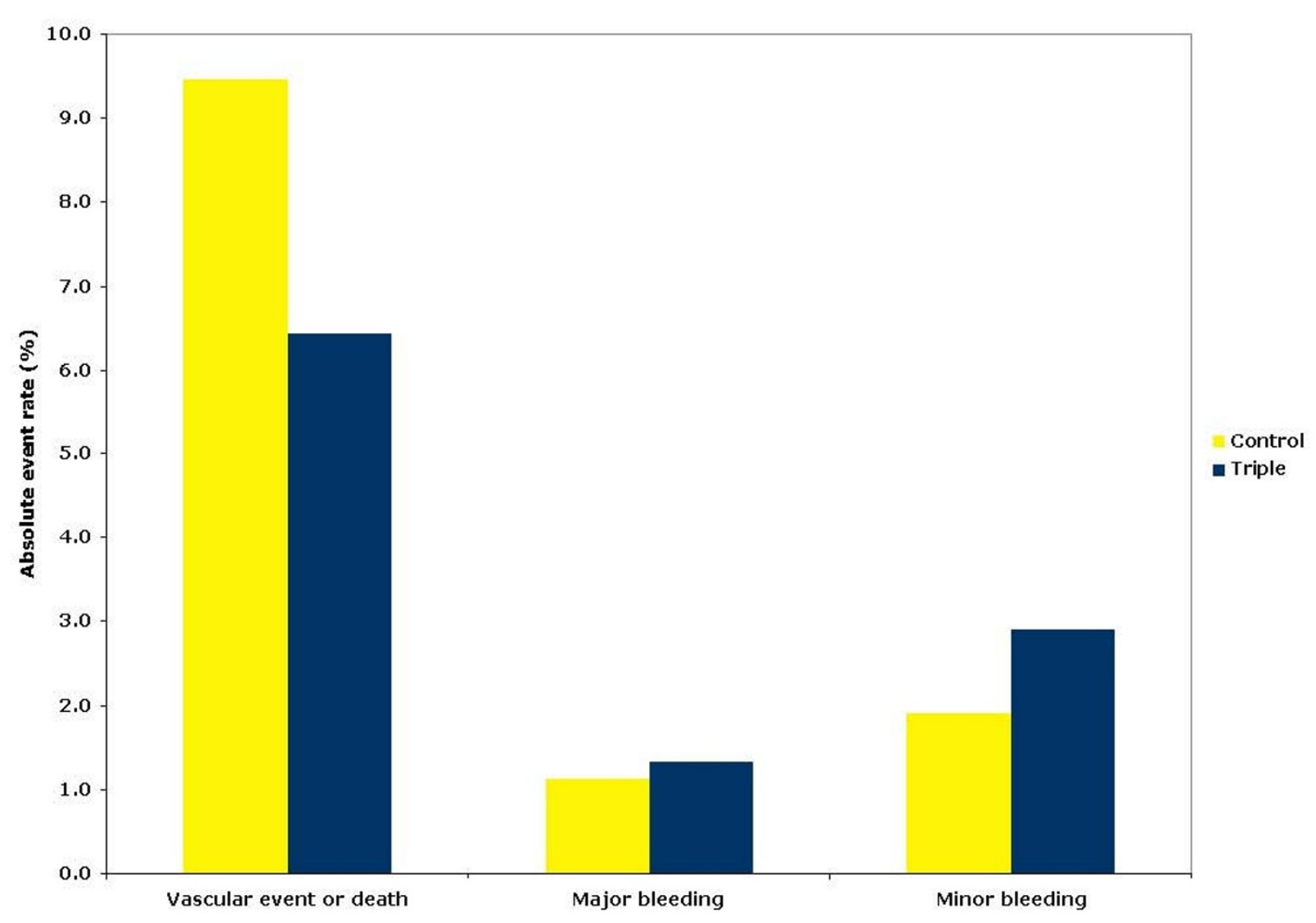

Figure 5 Absolute event rates for vascular event or death and bleeding.

sions and an eightfold increase in thrombocytopenia. Hence, the use of this enhanced platelet strategy depends on the patient population. The balance between benefit and hazard in patients treated for NSTE-ACS and STEMI lay in favour of giving three antiplatelet agents (typically aspirin, clopidogrel and an intravenous GPIIb/IIIa receptor antagonist) thereby supporting guidelines promoting this approach $[19,20]$. However, there were no or only few data available for the use of triple antiplatelet therapy for preventing recurrence in patients with chronic IHD, acute or chronic stroke or peripheral artery disease. Further research is now required to assess the role of triple antiplatelet therapy in such patients.

\section{Appendix}

Search strategy: MEDLINE (OVID)

01 triple antiplatelet therapy/

02. triple antiplatelet\$.tw.

03. triple therapy.tw.

04. combined antiplatelet/

05 . combined antiplatelet.tw.

06. aggressive antiplatelet therapy/

07. aggressive antiplatelet therapy.tw.
08. antiplatelet therapy/

09. antiplatelet therapy.tw.

10.1 or 2 or 3 or 4 or 5 or 6 or 7 or 8 or 9 or 10

11. aspirin/

12. dipyridamole/

13. clopidogrel/

14. ticlopidine/

15. prasugrel/

16. cilostazol/

17. triflusal/

18. glycoprotein IIb/IIIa receptor antagonists/

19. abciximab/

20. tirofiban/

21. eptifibatide/

22. 11 or 12 or 13 or 14 or 15 or 16 or 17 or 18 or 19 or 20 or 21

23. 10 and 22

24. ST elevation myocardial infarction/

25. STEMI.tw.

26. non-ST elevation acute coronary syndrome/

27. NSTEACS.tw.

28. acute coronary syndrome/

29. ACS.tw. 
30. stroke/

31. transient ischaemic attack/

32. TIA.tw.

33. acute limb ischaemia/

34. peripheral arterial disease/

35. peripheral vascular disease/

36. PVD.tw.

37. 24 or 25 or 26 or 27 or 28 or 29 or 30 or 31 or 32 or 33 or 34 or 35 or 36

38. 23 and 37

39. randomized controlled trials/

40. randomized-controlled-trial.pt.

41. controlled-clinical-trial.pt.

42. random allocation/

43. double-blind method/

44. single-blind method/

45. 39 or 40 or 41 or 42 or 43 or 44

46. exp clinical trials/

47. clinical-trial.pt.

48. (clin\$ adj trial\$).ti, ab.

49. ((singl\$ or doubl\$ or trebl\$ or tripl\$) adj (blind\$)).ti, ab.

50. random\$.ti, ab.

51.46 or 47 or 48 or 49 or 50

52. research design/

53. comparative study/

54. exp evaluation studies/

55. follow-up studies/

56. prospective studies/

57. (control\$ or prospective\$ or volunteer\$).ti, ab.

58.53 or 54 or 55 or 56 or 57

59.45 or 51 or 52 or 58

60.38 and 59

\section{Abbreviations}

IHD: ischaemic heart disease; iv: intravenous; MI: myocardial infarction; NSTEACS: non-ST elevation acute coronary syndrome; PCl: percutaneous coronary intervention; PVD: peripheral vascular disease; STEMI: ST elevation myocardial infarction; TIA: transient ischaemic attack; VE: vascular events.

\section{Competing interests}

CG and RW have no competing interests. PB is the Chief Investigator of two trials of triple antiplatelet therapy for stroke prevention, one completed and one ongoing http://www.tardistrial.org/[40].

\section{Authors' contributions}

All authors contributed equally to this work. CG was involved with searches for studies, input of data, analysis and writing. RW participated in searches for studies and writing. PB was involved with the design, development of search strategies, analysis and writing. All authors read and approved the final manuscript.

\section{Acknowledgements}

The Division of Stroke receives core funding from The Stroke Association (UK) PB is The Stroke Association Professor of Stroke Medicine. The funding source and trialists and pharmaceutical companies involved in the included studies had no involvement in this study.

\section{Author Details}

1Stroke Trials Unit, Institute of Neuroscience, Division of Stroke, University of Nottingham, City Hospital campus, Nottingham NG5 1PB, UK and 2Division of Cardiovascular Medicine, D Floor, South Block, University Hospital, Queen's Medical Centre, Nottingham NG7 2UH, UK
Received: 16 November 2009 Accepted: 16 June 2010

Published: 16 June 2010

References

1. Awtry EH, Loscalzo J: Aspirin. Circulation 2000, 101:1206-1218.

2. Cruz-Fernandez JM: Antiplatelet drugs in the treatment of acute coronary syndromes: Focus on cyclooxygenase inhibitors. European Heart J 2004, 3(Supplement 1):123-130.

3. Behan MWH, Storey RF: Antiplatelet therapy in cardiovascular disease. Postgrad Med J 2004, 80:155-164.

4. Born G, Patrono C: Antiplatelet drugs. Brit J Pharmacol 2006, 147:S241-251

5. Antiplatelet Trialists' Collaboration: Collaborative overview of randomised trials of antiplatelet therapy - I: prevention of death, myocardial infarction, and stroke by prolonged antiplatelet therapy in various categories of patients. BMJ 1994, 308:81-106.

6. Chew DP, Bhatt DL, Sapp S, Topol EJ: Increased mortality with oral platelet glycoprotein IIb/IIla antagonists: a meta-analysis of phase III multicenter randomized trials. Circulation 2001, 103(2):201-206.

7. Antithrombotic Trialists Collaboration: Collaborative meta-analysis of randomised trials of antiplatelet therapy for prevention of death, myocardial infarction, and stroke in high risk patients. BMJ 2002, 324(7329):71-86

8. Diener HC, Cunha L, Forbes C, Sivenius J, Smets P, Lowenthal A: European Stroke Prevention Study 2. Dipyridamole and acetylsalicylic acid in the secondary prevention of stroke. J Neurol Sci 1996, 143:1-13.

9. CAPRIE Steering Committee: A randomised, blinded, trial of clopidogrel versus aspirin in patients at risk of ischaemic events (CAPRIE). Lancet 1996, 348:1329-1339.

10. Matias-Guiu J, Ferro JM, Sabin JA, Torres F, Jimenez MD, Lago A, Melo T, Tong DC: Comparison of triflusal and aspirin for prevention of vascular events in patients after cerebral infarction: The TACIP study: A randomised, double-blind, multicenter trial. Stroke 2003, 34:840-848.

11. Huang $Y$, Cheng $Y$, Wu J, Li YX, Hong Z, Shang W, Ding M, Gao X, Fan D, Zeng J, et al:: Cilostazol versus Aspirin for Secondary Ischaemic Stroke Prevention cooperation investigators: Cilostazol as an alternative to aspirin after ischaemic stroke: a randomised, double-blind, pilot study. Lancet Neurol 2008, 7:494-499.

12. Yusuf S, Zhao F, Mehta SR, Chrolavicius S, Tognoni G, Fox KK, Clopidogrel in Unstable Angina to Prevent Recurrent Events Trial Investigators: The clopidogrel in unstable angina to prevent recurrent events trial investigators: Effects of clopidogrel in addition to aspirin in patients with acute coronary syndromes without st-segment elevation. New Eng J Med 2001, 345(7):494-502.

13. Steinhubl SR, Berger PB, Mann JT, Fry ETA, DeLago A, Wilmer C, Topol EJ, CREDO Investigators: Early and sustained dual oral antiplatelet therapy following percutaneous coronary invention: a randomized controlled trial. JAMA 2002, 288(19):2411-2420.

14. Sabatine MS, Cannon CP, Gibson CM, Lopez-Sendon JL, Montalescot G, Theroux P, Claeys MJ, Cooks F, Hill KA, Skene AM, CLARITY-TIMI 28 Investigators, et al:: Addition of clopidogrel to aspirin and fibrinolytic therapy for mocardial infarction with ST-segment elevation. New Eng J Med 2005, 352(12):1179-1189.

15. COMMIT (Clopidogrel and Metroprolol in myocardial infarction trial) collaborative group: Addition of clopidogrel to aspirin in 45852 patients with acute myocardial infarction: randomised placebo-controlled trial. Lancet 2005, 366(5):1607-1621.

16. The ESPRIT Study Group: Aspirin plus dipyridamole versus aspirin alone after cerebral ischaemia of arterial origin (ESPRIT): randomised controlled trial. Lancet 2006, 367:1665-1673

17. National Institute for Health and Clinical Excellence: Clopidogrel and modified release dipyridamole in the prevention of occlusive vascular events, 2005. [http://www.nice.org.uk/nicemedia/pdf/ TA090guidance.pdf

18. Silber S, Albertsson P, Aviles FF, Camici PG, Colombo A, Hamm C, Jorgensen E, Marco J, Nordrehaug JE, Ruzyllo W, Task Force for Percutaneous Coronary Interventions of the European Society of Cardiology: Guidelines for percutaneous coronary interventions, et al.: The Task Force for Percutaneous Coronary Interventions of the European Society of Cardiology. Eur Heart J 2005, 26(8):804-847.

19. Van de Werf F, Bax J, Betriu A, Blomstrom-Lundqvist C, Crea F, Falk V, Filippatos G, Fox K, Huber K, Kastrati A: Management of acute myocardial infarction in patients presenting with persistent ST-segment elevation: 
the Task Force on the Management of ST-Segment Elevation Acute Myocardial Infarction of the European Society of Cardiology. Eur Heart J 2008, 29(23):2909-2945.

20. Bassand JP, Hamm CW, Ardissino D, Boersma E, Budaj A, Fernandez-Aviles F, Fox KA, Hasdai D, Ohman EM, Wallentin L, Wijns W: Guidelines for the diagnosis and treatment of non-ST-segment elevation acute coronary syndromes. Eur Heart J 2007, 28(13):1598-1660.

21. Diener HC, Bogousslavsky J, Brass LM, Cimminiello C, Csiba L, Kaste M, Leys D, Matias-Guiu J, Rupprecht HJ, investigators fM: Aspirin and clopidogrel compared with clopidogrel alone after recent ischaemic stroke or transient ischaemic attack in high-risk patients (MATCH): randomised, double-blind, placebo-controlled trial. Lancet 2004, 364:331-337.

22. Bhatt DL, Fox KAA, Werner Hacke CB, Berger PB, Black HR, Boden WE, Cacoub P, Cohen EA, Creager MA, Easton JD, CHARISMA Investigators, et al:: Clopidogrel and aspirin versus aspirin alone for the prevention of atherothrombotic events. New Eng J Med 2006, 354:1706-1717.

23. Sacco RL, Diener HC, Yusuf S, Cotton D, Ounpuu S, Lawton WA, Palesch Y, Martin RH, Albers GW, Bath P, PRoFESS Study Group, et al:: Aspirin and Extended-Release Dipyridamole versus Clopidogrel for Recurrent Stroke. N Engl J Med 2008, 359:1238-1251.

24. Singh I, Shafiq N, Pandhi P, Reddy S, Pattanaik S, Sharma Y, Malhotra S: Triple antiplatelet therapy vs. dual antiplatelet therapy in patients undergoing percutaneous coronary intervention: an evidence-based approach to answering a clinical query. Br J Clin Pharmacol 2009, 68(1):4-13.

25. Bertrand $M E$, van Belle E: Triple antiplatelet treatment in patients presenting with non-ST-segment elevation acute coronary syndromes. Eur Heart J 2006, 8(Supplement G):G59-63.

26. Higgins JPT, Green S: Cochrane Handbook For Systematic Reviews of Interventions. London: Wiley Interscience; 2008

27. Egger M, Davey Smith G, Schneider M, Minder C: Bias in meta-analysis detected by a simple, graphical test. BMJ 1997, 315:629-634

28. Stone GW, Grines CL, Cox DA, Garcia E, Tcheng JE, Griffin JJ, Guagliumi G, Stuckey T, Turco M, Carroll JD, Controlled Abciximab and Device Investigation to Lower Late Angioplasty Complications (CADILLAC) Investigators, et al: Comparison of angioplsty with stenting with or without abciximab, in acute myocardial infarction. New Eng J Med 2002, 346(13):957-66

29. Ernst NM, Suryapranata H, Miedema K, Slingerland RJ, Ottervanger JP, Hoorntje JCA, Gosselink ATM, Dambrink JH, de Boer MJ, Zijlstra F, van't Hof AW: Achieved platelet aggregation inhibition after different antiplatelet regimens during percutaneous coronary intervention for ST-segment elevation myocardial infarction. J Am Coll Cardio/ 2004, 44(6):1187-1193.

30. Neumann F-J, Kastrati A, Schmitt C, Blasini R, Hadamitzky M, Mehilli J, Gawaz M, Schleef M, Seyfarth M, Dirschinger J, Schömig A: Effect of glycoprotein Ilb/llla receptor blockade with abciximab on clinical and angiographic restenosis rate after the placement of coronary stents following acute myocardial infarction. J Am Coll Cardiol 2000, 35(4):915-921.

31. Neumann F-J, Blasini R, Schmitt C, Alt E, Dirschinger J, Gawaz M, Kastrati A, Schomig A: Effect of glycoprotein Ilb/llla receptor blockade on recovery of coronary flow and left ventricular function after the placement of coronary-artery stens in acute myocardial infarction. Circulation 1998, 98:2695-2701

32. Pretronio AS, Rovai D, Musumeci G, Baglini R, Nardi C, Limbruno U, Palagi C. Volterrani D, Mariani M: Effects of abciximab on microvascular integrity and left ventricular functional recovery in patients with acute infarction treated by primary coronary agioplasty. Eur Heart J 2003, 24:67-76.

33. Kim JY, Lee K, Shin M, Ahn M, Choe H, Yoo BS, Yoon J, Choe KH, Lee SH: Cilostazol could ameliorate platelet responsiveness to clopidogrel in patients undergoing primary percutaneous coronary intervention. Circulation J 2007, 71:1867-1872.

34. Claeys MJ, van der Planken MG, Bosmans JM, Michiels JJ, Vertessen F, van der Goten P, Wuyts FL, Wrints CJ: Does pre-treatment with aspirin and loading dose clopidogrel obviate the need for a lycoprotein Ilb/llla antagonists during elective coronary stenting? A focus on periprocedural myonecrosis. Eur Heart J 2005, 26:567-575.
35. ESPRIT Investigators: Novel dosing regimen of eptifibatide in planned coronary stent implantation (ESPRIT): a randomised, placebocontrolled trial. Lancet 2000, 356:2037-2044.

36. Eisenberg MJ, Jamal S: Glycoprotein Ilb/Illa inhibition in the setting of acute ST-segment elevation myocardial infarction. J Am Coll Cardiol 2003, 42(1):1-6.

37. de Queiroz Fernandes Araújo JO, Veloso HH, Braga De Paiva JM, Filho MW Vincenzo De Paola AA: Efficacy and safety of abciximab on acute myocardial infarction treated with percutaneous coronary interventions: a meta-analysis of randomized, controlled trials. Am Heart J 2004, 148(6):937-943

38. De Luca G, Marino P: Facilitated angioplasty with combo therapy among patients with ST-segment elevation myocardial infarction: a meta-analysis of randomized trials. Am J Emerg Med 2009, 27(6):683-690.

39. Jeremias A, Vasu S, Gruberg L, Kastrati A, Stone GW, Brown DL: Impact of abciximab on mortality and reinfarction in patients with acute STsegment elevation myocardial infarction treated with primary stenting. Catheter Cardiovasc Interv 2009, 75:895-902.

40. Sprigg N, Gray $\sqcup$, England T, willmot MR, Zhao L, Sare GM, Bath PMW: A randomised controlld trial of triple antiplatelet therapy (Aspirin, Clopidogrel and Dipyridamole) in the secondary prevention of stroke: Safety, tolerability and feasibility (ISRCTN 83673558). PLoS One 2008, 3:e2852.

41. Valgimigli M, Percoco G, Barbieri D, Ferrari F, Guardigli G, Parrinello G, Soukhomovskaia O, Ferrari R: The additive value of tirofiban administered with the high-dose bolus in the prevention of ischaemic complications during high-risk coranary angioplasty. J Am Coll Cardiol 2004, 44(1):14-19.

42. Rasoul S, Ottervanger JP, Boer M, Miedema K, Hoorntje JCA, Gosselink M, Zijlsta F, Suryapranata H, Dambrink JE, Hof AWJ: A comparison of dual vs. triple antiplatelet therapy in patients with non-ST-segment elevation acute coronary syndrome: results of the ELISA - 2 trial. Eur Heart J 2006, 27:1401-1407.

43. Kastrati A, Mehilli J, Neumann F, Dotzer F, Berg J, Bollwein H, Graf I, Ibrahim M, Pache J, Seyfarth M, et al.: Intracoronary Stenting and Antithrombotic: Regimen Rapid Early Action for Coronary Treatment 2 (ISAR-REACT 2) Trial Investigators: Abciximab in patients with acute coranary syndromes undergoing percutaneous coranary intervention after clopidogrel pretreatment. JAMA 2006, 295(13):1531-1538.

44. Gibson CM, Morrow DA, Murphy SA, Palabrica TM, Jennings LK, Stone PH, Lui HH, Bulle T, Lakkis N, Kovach R, TIMI Study Group, et al:: A randomized trial to evaluate the relative protection against post-percutaneous coronary intervention microvascular dysfunction, ischemia, and inflammation among antiplatelet and antithrombotic agents: The PROTECT-TIMI-30 trial. J Am Coll Cardiol 2006, 47:2364-2373.

45. Montalescot G, Barragan P, Wittenberg O, Ecollan P, Elhadad S, Villain P, Boulenc JM, Morice MC, Maillard L, Pansiéri M, Choussat R, Pinton P, ADMIRAL Investigators: Platelet glycoprotein Ilb/Illa inhibition with coronary stenting for acute myocardial infarction. N Eng/ J Med 2001, 344(25):1895-1903

46. Antoniucci D, Rodriguez A, Hempel A, Valenti R, Migliorini A, Vigo F, Parodi G, Fernandez-Pereira C, Moschi G, Bartorelli A, et al:: A randomized trial comparing primary infarct artery stenting with or without abciximab in acute myocardial infarction. J Am Coll Cardiol 2003, 42:1879-1885.

47. Stone GW, Grines CL, Cox DA, Garcia E, Tcheng JE, Griffin JJ, Guagliumi G Stuckey T, Turco M, Carroll JD, Controlled Abciximab and Device Investigation to Lower Late Angioplasty Complications (CADILLAC) Investigators, et al: Comparison of angioplasty with stenting, with or without abciximab in acute myocardial infarction. N Engl J Med 2002, 346(13):957-966.

48. Ernst NMSKJ, Suryapranata $H$, Miedema K, Slingerland RJ, Ottervanger JP, Hoorntje JCA, Gosselink ATM, Dambrink JE, de Boer M, Zijlstra F, van 't Hof AW: Achieved platelet aggregation inhibition after different antiplatelet regimens during percutaneous coronary intervention for ST-segment elevation myocardial infarction. J Am Coll Cardiol 2004, 44:1187-1193.

49. Petronio AS, Rovaib D, Musumecia G, Baglinia R, Nardia C, Limbrunoa U, Palagia C, Volterranic D, Mariania M: Effects of abciximab on microvascular integrity and left ventricular functional recovery in patients with acute infarction treated by primary coronary angioplasty. Eur Heart J 2003, 24(1):67-76. 
50. Kim JY, Lee K, Shin M, Ahn M, Choe H, Yoo BS, Yoon J, Choe KH, Lee SH: Cilostazol could ameliorate platelet responsiveness to clopidogrel in patients undergoing primary percutaneous coronary intervention. Circ J 2007, 71(12):1867-1872.

51. Claeys MJ, Planken MGV, Bosmans JM, Michiels JJ, Vertessen F, Goten PVD, Wuytes FL, Vrints CJ: Does pre-treatment with aspirin and loading dose clopidogrel obviate the need for glycoprotein Ilb/llla antagonists during elective coronary stenting? A focus on peri-procedural myonecrosis. Eur Heart J 2005, 26:567-575

52. EPISTENT Investigators: Randomised placebo-controlled and balloonangioplasty-controlled trial to assess safety of coronary stenting with use of platelet glycoprotein-IIb/Illa blockade. Lancet 1998, 352:87-92.

53. Kastrati A, Mehilli J, Schuhlen H, Dirschinger J: A clinical trial of abciximab in elective percutaneous coronary intervention after pretreatment with clopidogrel. New Eng J Med 2004, 350:232-238.

54. Hausleiter J, Kastrati A, Mehilli J, Schuhlen H, Pache J, Dotzer F, Glatthor C, Siebert S, Dirschinger J, Schomig A: A randomised trial comparing phosphorylcholine-coated stenting with balloon angioplasty as well as abciximab with placebo for restenosis reduction in small coranary arteries. J Internal Med 2004, 256:388-397.

55. Mehilli J, Kastrati A, Schuhlen H, Dibra A, Dotzer F, Beckerath N, Bollwein H, Pache J, Dirschinger J, Berger PP, Schömig A, Intracoronary Stenting and Antithrombotic Regimen: Is Abciximab a Superior Way to Eliminate Elevated Thrombotic Risk in Diabetics (ISAR-SWEET) Study Investigators: Randomised clinical trial of abciximab in diabetic patients undergoing elective percutaneous coranary interventions after treatement with a high loading dose of clopidogrel. Circulation 2004, 110:3627-3635.

56. Bonz AW, Lengenfelder B, Strotmann J, Held S, Turschner O, Harre K, Wacker C, Waller C, Kochsiek N, Meesmann M, Neyses L, et al.: Efffects of additional temporary glycoprotein IIb/IIla receptor inhibition on troponin relese in elective percutaneous coranary interventions after petreatment with aspirin and clopidogrel. J Am Coll Cardiol 2002, 40(4):662-668.

57. Mardikar HM, Hiremath MS, Moliterno DJ, Mathew R, Arora R, Deo D, Hiremath JS, Deshpande NV, Khan A, Joseph J, Mukherjee D: Optimal platelet inhibition in patients undergoing $\mathrm{PCl}$ : data from the Multicenter Registry of High-Risk Percutaneous Coronary Intervention and Adequate Platelet Inhibition (MR PCI) study. Am Heart J 2007, 154(2):e341-345.

58. Lee SW, Park S, Kim YH, Yun SC, Park DW, Lee CW, Hong MK, Kim HS, Ko JK, Park JH, DECLARE-Long Study Investigators, et al:: Comparison of triple versus dual antiplatelet therapy after drug-eluting stent implantation (from the DECLARE-Long trial). Am J Cardiol 2007, 100(7):1103-1108.

59. Lee SW, Park SW, Kim YH, Yun SC, Park DW, Lee CW, Hong MK, Kim HS, Ko $\mathrm{JK}$, Park JH, et al:: Drug-eluting stenting followed by cilostazol treatment reduces late restenosis in patients with diabetes mellitus. J Am Coll Cardiol 2008, 51:1181-1187.

60. Min PK, Jung JH, Ko YG, Choi D, Jang Y, Shim WH: Effect of cilostazol on in-stent neointimal hyperplasia after coronary artery stenting. Circ J 2007, 71(11):1685-1690.

61. Douglas JS Jr, Holmes DR Jr, Kereiakes DJ, Grines CL, Block E, Ghazzal ZM, Morris DC, Liberman H, Parker K, Jurkovitz C, Cilostazol for Restenosis Trial (CREST) Investigators, et al:: Coronary stent restenosis in patients treated with cilostazol. Circulation 2005, 112(18):2826-2832.

62. Han Y, Li Y, Wang S, Jing Q, Wang Z, Wang D, Shu Q, Tang X: Cilostazol in addition to aspirin and clopidogrel improves long-term outcomes after percutaneous coronary interve ntion in patients with acute coronary syndromes: a randomized, controlled study. Am Heart J 2009, 157(4):733-739

Pre-publication history

The pre-publication history for this paper can be accessed here: http://www.biomedcentral.com/1741-7015/8/36/prepub

doi: $10.1186 / 1741-7015-8-36$

Cite this article as: Geeganage et al., Triple antiplatelet therapy for preventing vascular events: a systematic review and meta-analysis BMC Medicine 2010, 8:36

\section{Submit your next manuscript to BioMed Central} and take full advantage of:

- Convenient online submission

- Thorough peer review

- No space constraints or color figure charges

- Immediate publication on acceptance

- Inclusion in PubMed, CAS, Scopus and Google Scholar

- Research which is freely available for redistribution 